\title{
Article
}

\section{Potential Use of Indoor Living Walls in Canadian Dwellings}

\author{
Daria Smolova ${ }^{1}$ and Avi Friedman ${ }^{2, *}$ \\ 1 School of Architecture, McGill University, Montreal, QC H3A 0C2, Canada; daria.smolova@mail.mcgill.ca \\ 2 Affordable Homes Research Group, School of Architecture, McGill University, \\ Montreal, QC H3A 0C2, Canada \\ * Correspondence: avi.friedman@mcgill.ca
}

\section{check for}

updates

Citation: Smolova, D.; Friedman, A. Potential Use of Indoor Living Walls in Canadian Dwellings. J 2021, 4 , 116-130. https://doi.org/10.3390/ j4020010

Academic Editor: Ashok Kumar

Received: 6 April 2021

Accepted: 28 April 2021

Published: 7 May 2021

Publisher's Note: MDPI stays neutral with regard to jurisdictional claims in published maps and institutional affiliations.

Copyright: (c) 2021 by the authors. Licensee MDPI, Basel, Switzerland. This article is an open access article distributed under the terms and conditions of the Creative Commons Attribution (CC BY) license (https:/ / creativecommons.org/licenses/by/ $4.0 /)$.

\begin{abstract}
Current social and environmental challenges have led to the rethinking of residential designs. Global warming, food insecurity, and, as a result, costly fresh produce are some of the causes of the reconsideration. Moreover, with obligatory isolation following the global COVID-19 pandemic, some are realizing the importance of nature and air quality in homes. This paper explores the potential integration of indoor living walls (ILWs) in Canadian homes for agricultural and air purification purposes. By reviewing a number of case studies, this paper investigates how the development of such walls can alter the traditional food production chain, while reducing environmental threats. The findings show that current indoor living wall practices can be transformed into a useful source of fresh food, and, to some degree, alter traditional food supply. They can also help in creating inexpensive methods of air purification.
\end{abstract}

Keywords: indoor living walls; vertical garden; urban agriculture; food production

\section{Introduction}

It has become apparent that global warming leads to an increase in environmental disasters, such as hurricanes and forest fires, that cause calamities worldwide. According to the World Health Organization (2014), in the years leading up to the 2030s, climate change will lead to the deaths of 38,000 seniors due to heat exposure and 95,000 children due to nutrition unsustainability [1]. Daily human activities such as fossil fuel burning, deforestation, and agriculture are the three most influential factors of global temperature change [2].

When considering food, the current life cycle of agricultural products consists of seven stages: food production, distribution and aggregation, processing, marketing, purchasing, preparation and consumption, and resource and waste recovery. Nearly $60 \mathrm{Mt} \mathrm{CO}_{2}$ eq (8.5\%) out of a total of $704 \mathrm{MtCO}_{2}$ eq (100\%) are emissions caused by agricultural processes, while $199 \mathrm{Mt} \mathrm{CO}_{2}$ eq (28.3\%) falls on energy consumption and transportation, which is a critical stage of the entire food chain [3] (Figure 1). Besides energy and water expenditure, waste generation used for packaging is dramatic and directly harms the environment. According to Kissinger (2012), for example, 30\% of all agricultural and food products consumed in Canada are imported from other countries and continents, which results in "food miles" of more than 61 billion tonnes km [4].

By analyzing the breakdown of $\mathrm{CO}_{2}$ emissions in Canada and its relation to fruits and vegetables (Figure 2), it is obvious that vegetated indoor living walls (ILWs) in residential properties can lower these staggering numbers.

With the constant population growth in Canada, cities are experiencing a considerable reduction of naturally vegetated cover. With the advent of ongoing construction, society has lost its significant connection with nature by leaving it far away in suburban places and saturating city life with soulless gray infrastructure. This problem directly affects and limits the potential spaces that can be converted for food production. Buildings should not only be a space for living and ongoing consumption but an interconnection between citizens and 
the environment [5]. According to Precht (2019), vertical farming can produce a diverse number of crops and plants per planted area without reliance on weather conditions [5].

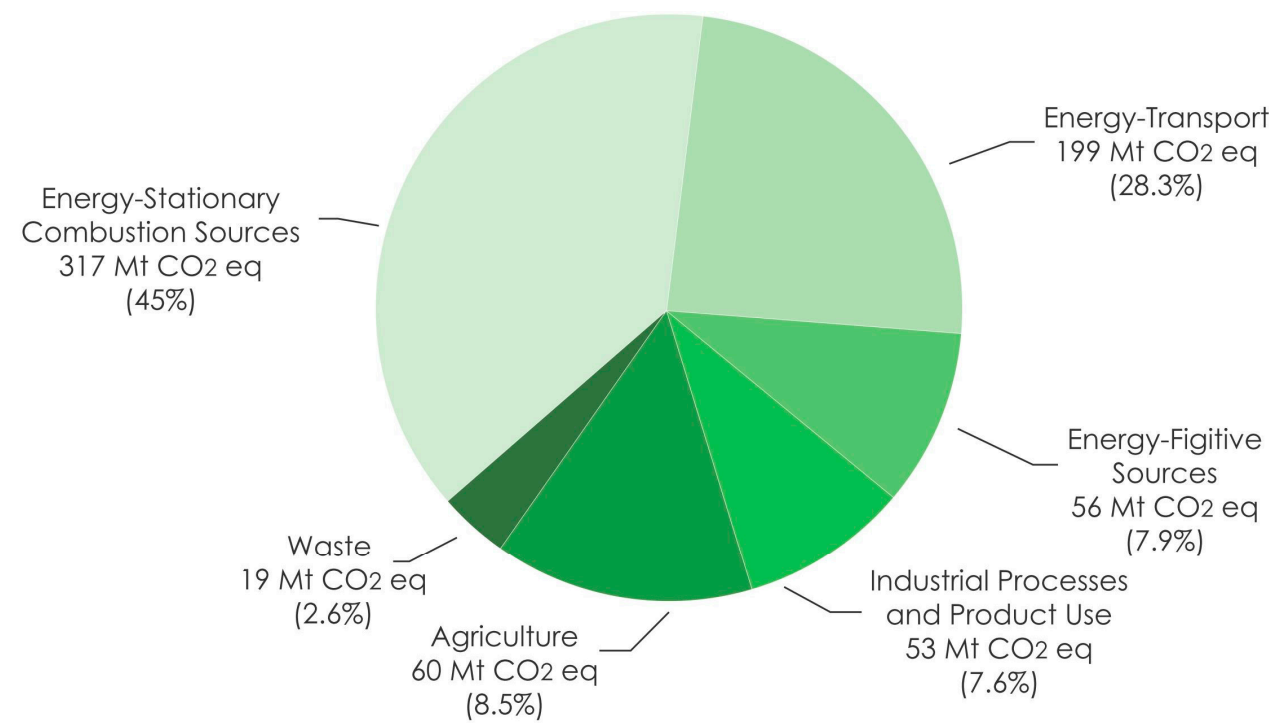

Figure 1. Breakdown of Canada's emissions by the Intergovernmental Panel on Climate Change sector (2016) [3].

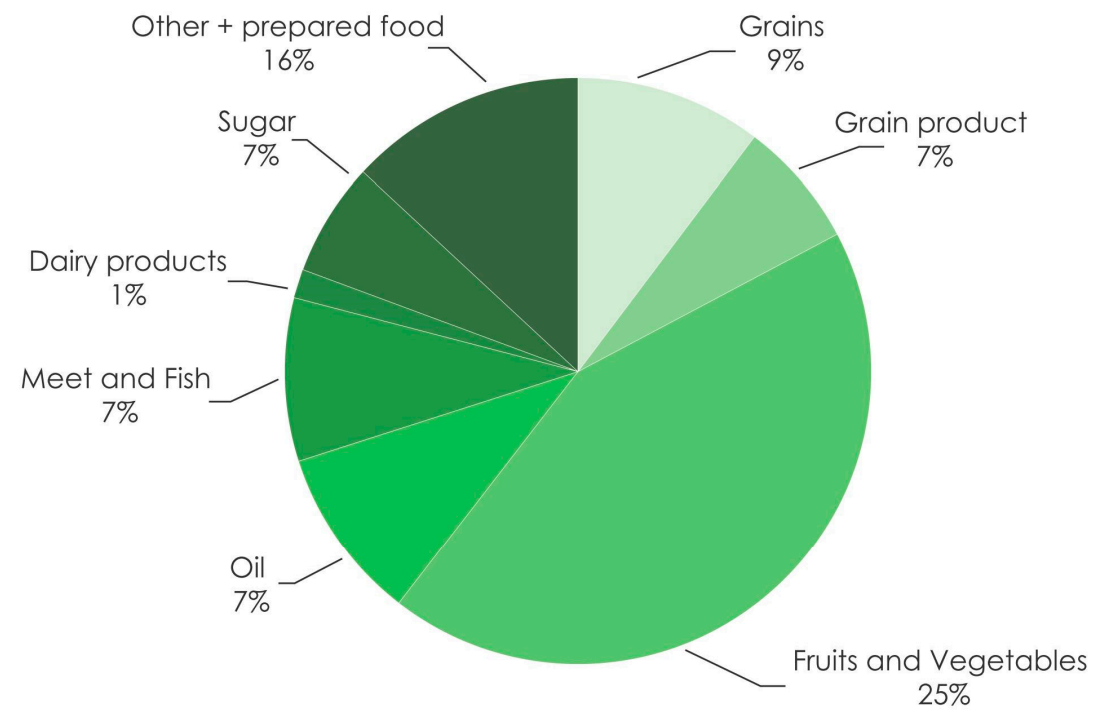

Figure 2. Canada's food miles related to $\mathrm{CO}_{2}$ emissions by specific food group [4].

The price index for fresh vegetables and fruits has rapidly increased from 90-100 in 2004 to 130 in 2015 and is continuously rising [6]. Moreover, to propose a more accessible source of food, the Government of Canada supports the use of genetically modified crops that undoubtedly harms one's state of health.

The World Health Organization (WHO, 1999) states that people spend over $90 \%$ of their time indoors, but nearly nobody is aware of what the indoor air truly consists of [7]. These resources consist of particles and substances that constantly harm our health. It was concluded that the presence of indoor vertical gardens creates relatively lower temperatures and higher humidity levels [8]. On the other hand, in the winter season, living walls create thermal comfort conditions and provide various benefits to occupants [8].

The development of ILWs in Canadian dwellings might therefore become an incentive to improve climate change conditions and create a sustainable food system. The intercon- 
nection between the greenery of ILWs and human beings can provide a variety of social, global, and psychological benefits that in the future, can change our resource-intensive lifestyle. Although ILW systems are well established for commercial and public spaces, its possibility of food production in homes and affordability of the system have not been extensively studied. According to the authors of this paper, no work has been dedicated to an edible indoor living wall concept. The authors of this paper strongly believe that ILW systems have great potential to be used to grow food at home while providing air purification and psychological benefits to users. The primary goal of this review is to indicate that with a good understanding of living wall technologies and the use of the basic components, a living wall can be accessible and affordable to anyone to bring about its full efficiency.

\section{Living Wall Technology}

ILWs are composed of modular vertical systems, planted blankets, or prepared vegetated panels that are commonly made out of plastic, polystyrene, synthetic fabric, clay, metal, and concrete [9]. ILWs require structural support and includes a frame, which holds all of the components together and supports growing media and plants (Figure 3).

A continuous ILW system is based on the installation of a frame attached to the wall with a void space in between, which protects plants from humidity [10]. Following the frame, base panels form the next layer, which is covered with permeable material, including root proof screens stapled to the base of the system and cut into pockets for the insertion of plants individually [10].

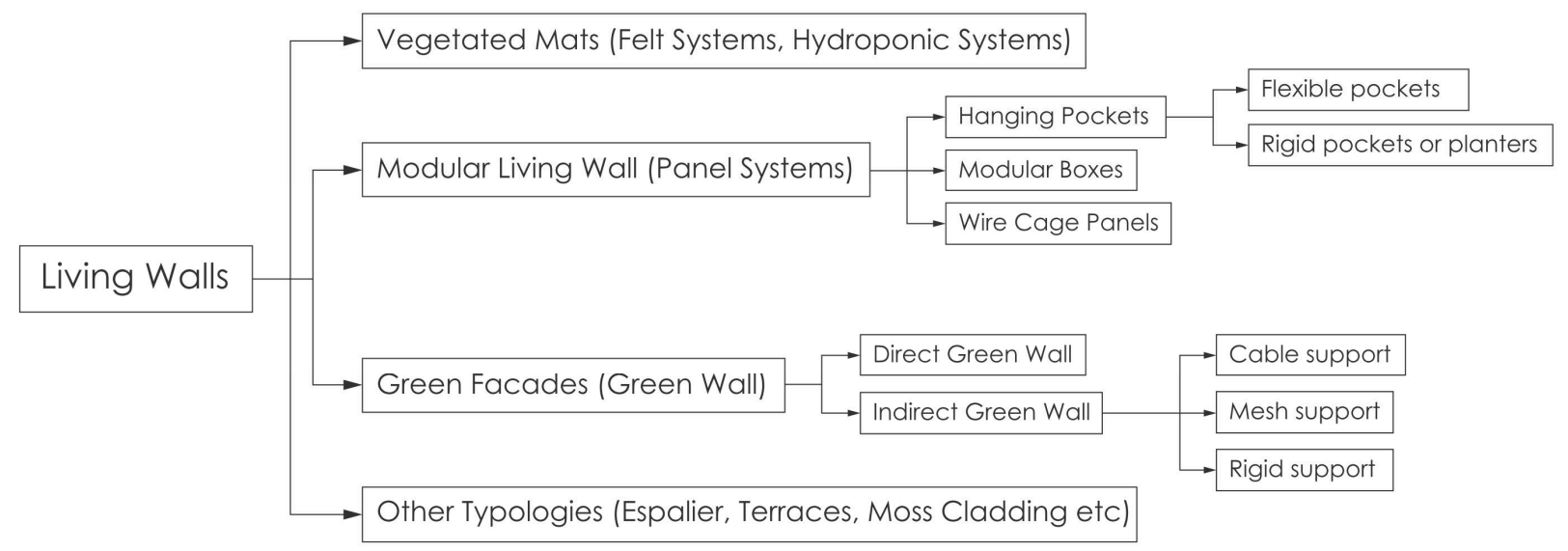

Figure 3. Classification of living wall typology reflected in the literature review [11].

Living walls can be characterized into hydroponic and soil-cell systems (Figure 4) [12]. Hydroponic systems usually use a dense mat and felt components as growing media [12]. This hydroponic system is lightweight and saturated with nutrients, where roots grow on and between layers of the chosen substrate [12]. Hydroponic ILW systems can be modular or composed of big panels fixed via brackets. On the other hand, soil-cell systems are subdivided into individual compartments and grouped together in panels to attach to the frame and control the growth of plants [12].

The irrigation system that provides the water needed for the plants depends on the type of ILW system that is chosen, the plant type, and the indoor conditions. The most important element of the irrigation system is the water tube located at the top connected to the central irrigation system, where water is distributed equally by the screens to all parts of the wall [10]. The water is usually enriched with nutrients, fertilizers, and minerals. ILWs can be fertilized with the application of substance into the irrigation water, which can be done automatically or manually by using granular or liquid substances [13]. 
The identification of suitable plant species is essential and guarantees the survival and prosperous stability of the food production [14]. During the selection process, users should think, in advance, about the rate of plant growth; the plants' weight; nutrient requirements; and sensitivity to local indoor context, such as temperature, moisture, height, and shade. The number of species grown on a single living wall can create root competition among the different or same species plants, which can be solved by using root growth strategies, such as strong avoidance or aggressive root growth [15-17].

Modular system

Hydropomic system

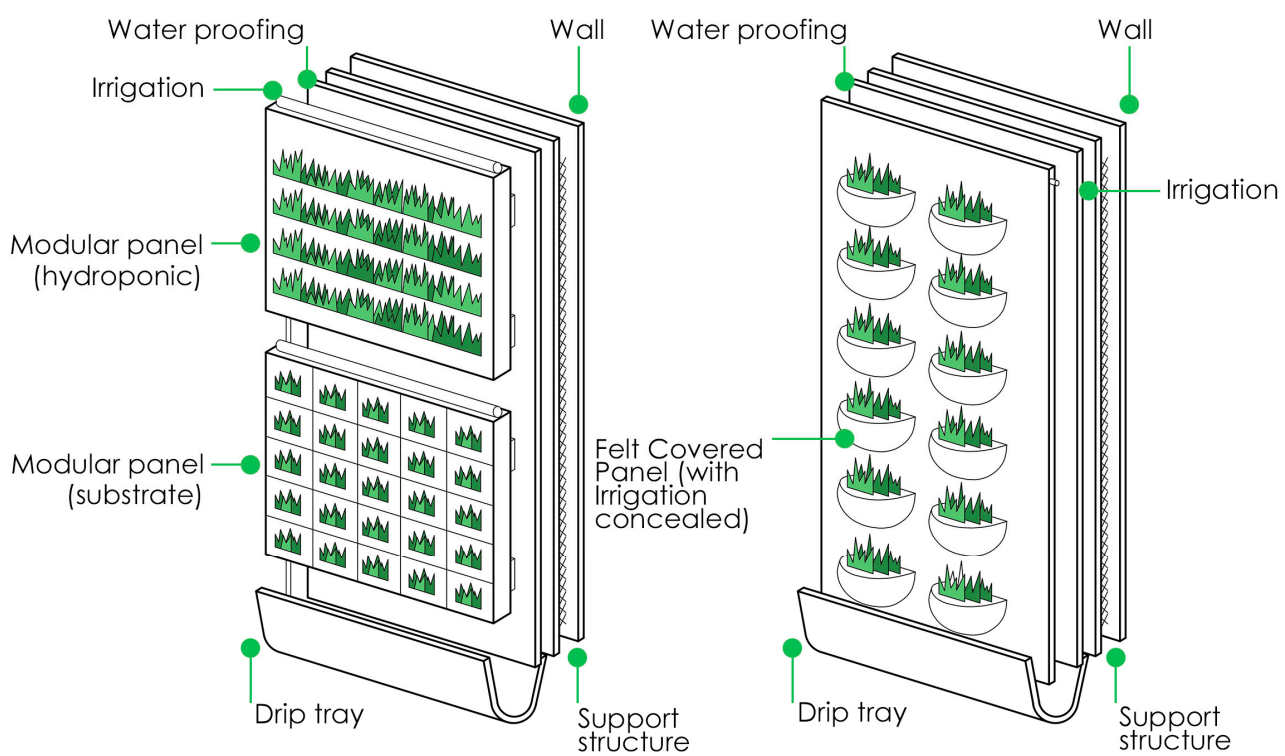

Figure 4. Types of living wall systems [18].

The most decisive factor that will enable a successfully implemented wall is ongoing maintenance. The automation of the basic living wall needs to allow the growth of healthy plants and consequently, reduce the maintenance demand [19]. Generally, plants are irrigated by an automatic system with prepared vertical and horizontal pipes behind the soil where water is equally distributed to the plants [20]. Routine maintenance includes the control of the irrigation system, a vegetation growth check, the examination of the harvest, and in-service control of materials and components of the ILW, whereas special maintenance will be composed of the reparation of the irrigation system, components, and anti-parasitic treatments [21].

Indoor living walls also require the development of a periodic lighting system suitable for all plants according to their needs [19]. Some of the most common sources of artificial lighting that can be used are incandescent, fluorescent, LED, halogen, and high-intensity discharge lamps. Based on ANS Global, the photosynthesis of plants requires at least 1000 lux intensity [22]. ILWs require the adjustment of color temperature according to the specific species of plant. The color temperature will determine the future of the plants and their ability to develop leaves, stems, and flowers [22]. For example, the color blue over $5000 \mathrm{~K}$ allows the growth of healthy leaves and stems, while red and orange colors between 2700 and $3000 \mathrm{~K}$ promotes flowering [22].

The integration of ILWs inside residential properties improves the efficiency of indoor spaces and provides ecological and environmental benefits to its users. An indoor vegetated living wall is a good way to create a biofilter for the indoor context that could potentially remove airborne pollutants and indoor contaminants from items such as furniture, machines, appliances, and cleaning equipment [23]. The World Health Organization (WHO) states that for the average person, over $90 \%$ of time is spent indoors [1,7]. Based on the Environmental Protection Agency, people who live and work in an environment of man-made materials inhale more than 300 pollutants every day [24]. According to 
Fell (2011), the existence of ILWs can result in better productivity and general health improvements [25].

The initial preparation of the ILW should begin with a study of the main components and factors, such as location, indoor climate, availability of materials, supporting structures, and irrigation methods. The plan for further installation would include the identification of structural support, irrigation and lighting system, a choice of waterproofing and matrix materials, and plant selection.

As shown in Figure 5, the flexibility of living wall systems is broad, and, therefore, they can be chosen according to home design and existing spatial conditions. The abundance of different systems enables the integration of a living wall to any interior setting whilst considering adaptability to existing furniture placement, available area, size, and vertical or horizontal surfaces, which means that the ILW system can adapt its own design without the disturbance of existing interior settings. The implementation of a living wall into a built home or apartment will require special attention regarding the location that would be most successful. Some of the criteria to underline are the lighting, moisture condition, and temperature condition that the chosen place can provide. The integration of an indoor living wall into a new home or apartment may create more flexibility and opportunities for the design due to the fact that the design of the space and the living wall are being evaluated uniformly.

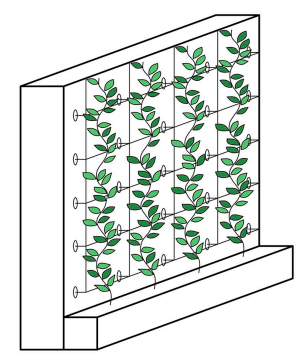

(a)

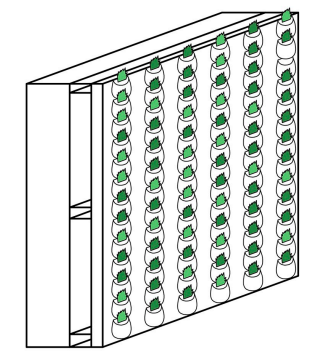

(d)

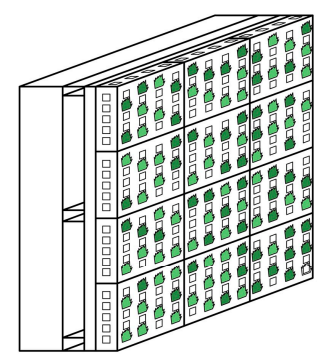

(g)

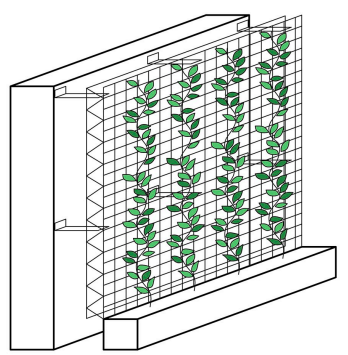

(b)

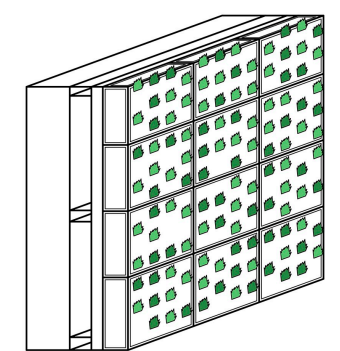

(e)

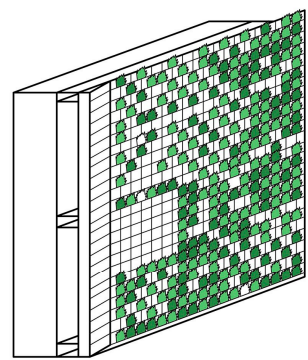

(h)

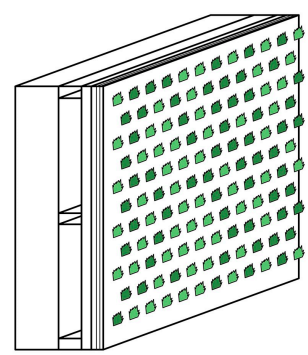

(c)

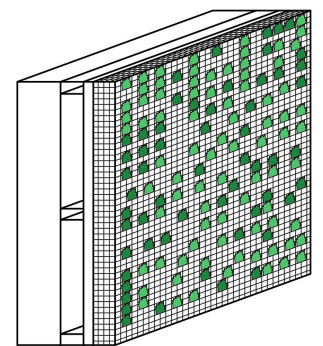

(f)

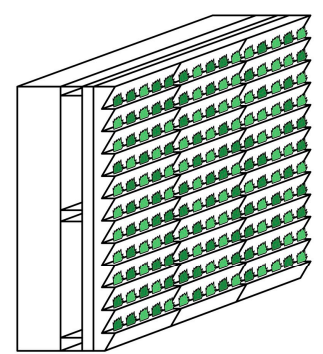

(i)

Figure 5. Diversity of living wall typologies [26]. (a) Indirect green facade with a two-dimensional trellis, (b) indirect green facade with a three-dimensional trellis, (c) vegetated mat living wall system, (d) hanging pocket living wall system, (e) framed box modular living wall system, (f) wire cage modular living wall system, (g) perforated box modular living wall system, (h) slanted cell box modular living wall system, and (i) through planters. 


\section{Living Wall in Practice}

The following five case studies are presented in order to indicate how current ILW systems work in practice. The examples of ILWs were chosen based on the diversity of the market and the set of components, which varies from one to the other. Each system represents a unique design approach adapted to interior settings and is therefore composed of individual components based on the primary function, indoor conditions, and client's requirements. The intention of this paper's main author was to illustrate that the broad range of current ILW systems can meet the target cost and the needs of the user. Additionally, these practices can serve a great foundation for future development of ILWs for food production.

\subsection{Versa Wall System}

The Versa Wall system concentrates on air purification and aesthetic purposes, cleaning the space from indoor air pollutants and filling the area with color and fresh air. The GSky system is based on irrigation by low-flow drip emitters, including the use of recycled materials and a highly efficient drainage system. The Versa Living Wall is a system that contains modular trays and is highly adjustable to interior design requirements. The fundamental component of the Versa Wall system includes the $25 \mathrm{~mm}$ pots that can be placed into the system, creating diverse patterns as well as a species selection that provides a high flexibility of design [27]. The main advantage of this system is that it does not require 're-potting', meaning that there will not be additional material expenses, and, thus, the pots can be used permanently, avoiding potential waste generation [27].

The Versa Wall (Figure 6) represents a self-contained automated system, which guarantees efficient water management and the prevention of soil or water spills. The trays of the Versa Wall system are designed to optimize water consumption through the recirculation of water through the plants and the automated pipes that allow its further reuse [27]. In this case, the Versa Wall is good for people who lack free time or are unable to manage watering and irrigation by hand.

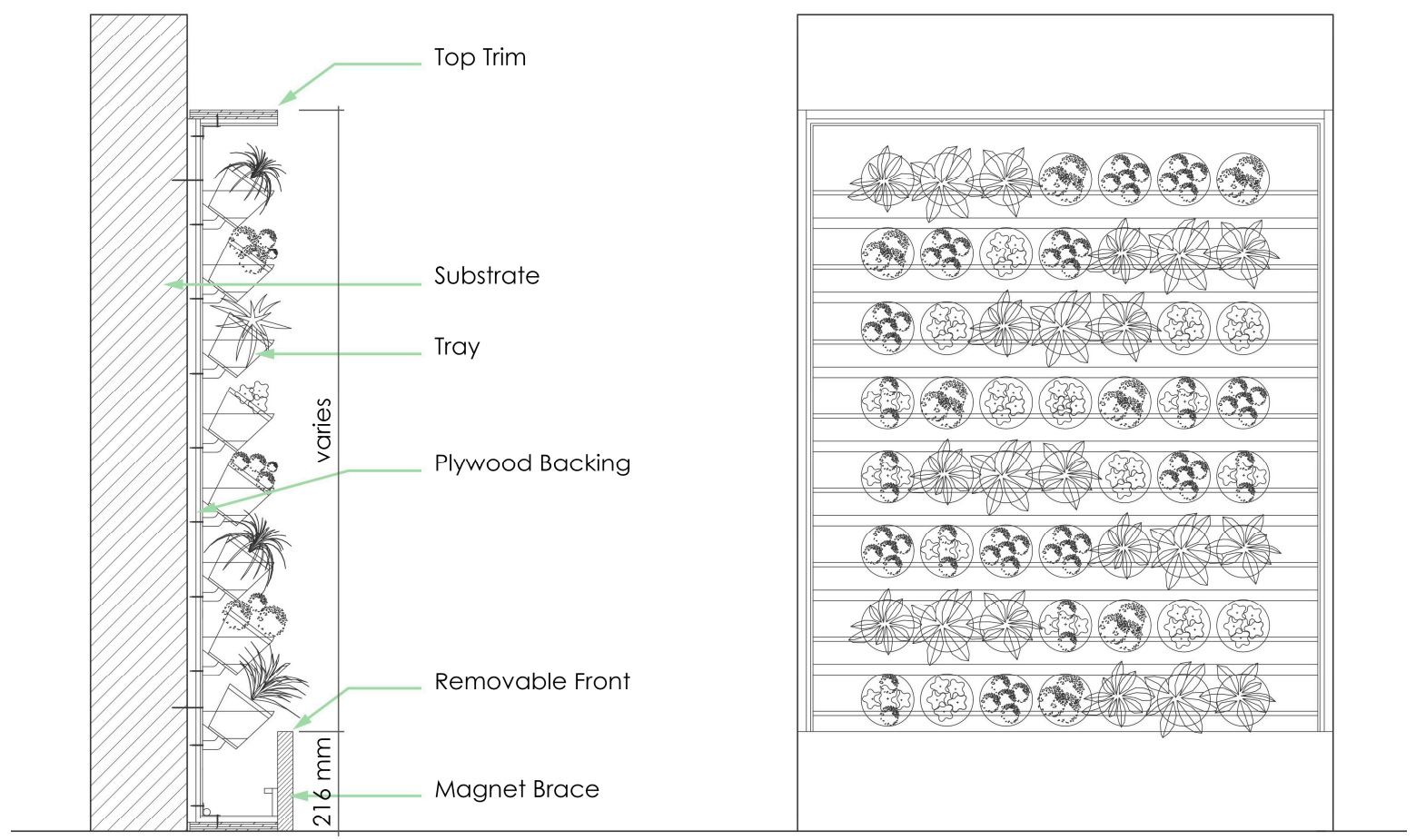

Figure 6. Living wall concept based on [28]. 


\subsection{ANS Living Wall}

The ANS Living Wall uses natural soil and recyclable modules (Figure 7), allowing plants to grow in their natural environment [22]. An ILW creates customized designs by adding a wide range of plant species, shapes, and patterns. The longevity of the system is protected by the presence of natural soil that preserves the plants' roots.

The ANS Living Wall consists of various components that should be fixed together one-by-one. One of its greatest advantages is the absence of man-made growing media, mineral wools, and other fibers. The modular system enables flexibility and convenience for the user. ANS Living Walls are efficient in providing proper heat reduction and cooling as well as the issue of energy consumption, which can help one save some money [22].

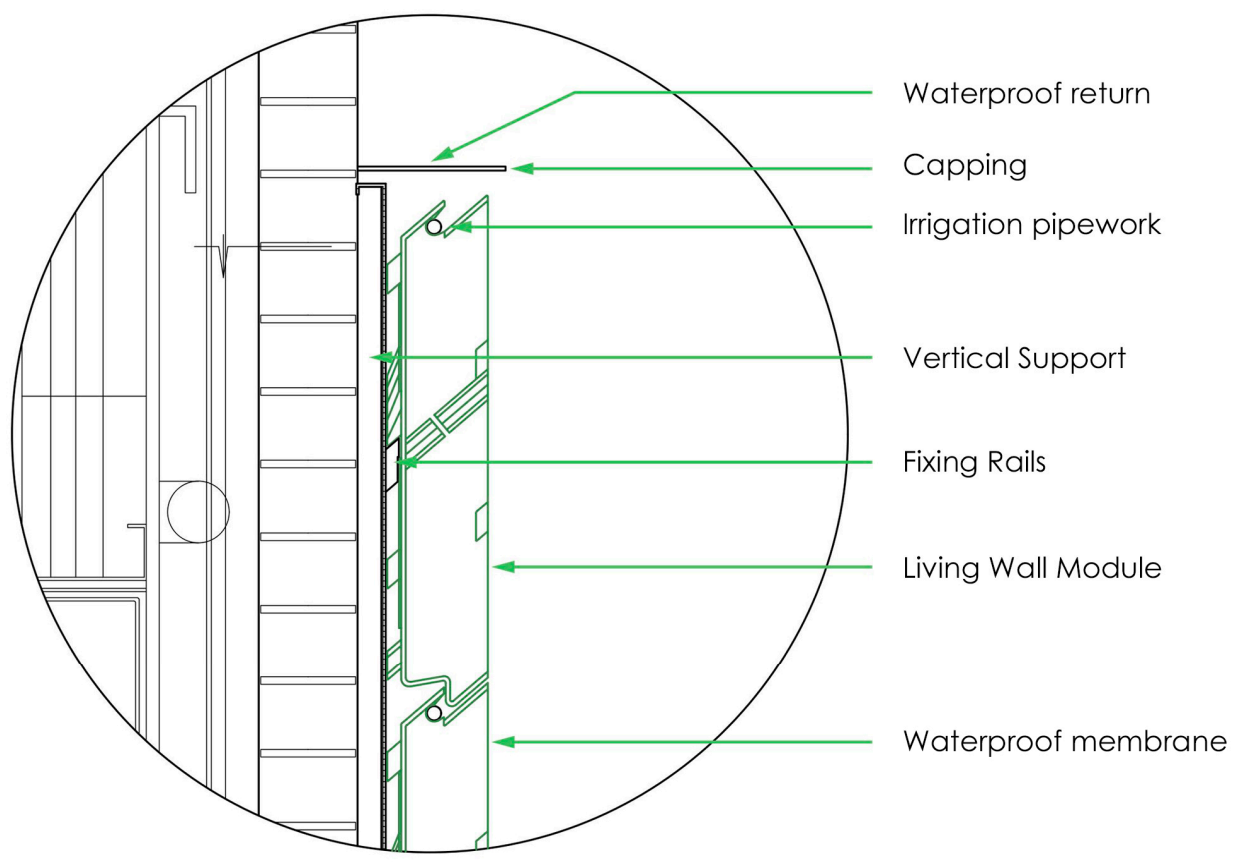

Figure 7. Living wall top section based on [29].

\subsection{Florafelt Living Wall System}

The Florafelt system (Figure 8) is made from recycled plastic water bottles and can be re-melted to create other products. The Florafelt living wall is an innovative and affordable design, which allows air penetration through the system and reduces the risk of structural damage. The system can be easily fixed onto a lightweight plastic board to keep the main wall dry [30]. Watering is ensured from the top in order to let water run down through the system. Roots grow into the moist fabric, which also allows the felt to gather nutrients.

The felt pockets are made from $100 \%$ recyclable non-woven fiber felt [31]. It has a great thermal insulation value and acoustical properties. The excess water can be reused and recycled either for further watering of the living wall or the watering of other plants. The living wall is highly efficient in optimizing indoor space by bringing benefits to a limited area. The Florafelt Compact Kit represents an affordable method for creating an ILW. One of the biggest advantages is not only its affordability but also its easy installation process. The flexibility of the system allows one to multiply the existing number of pockets by adding extra felt if needed.

\subsection{NAAVA Living Wall}

The NAAVA system (Figure 9) combines the flexibility, affordability, and innovativeness of ILWs. Naava One absorbs the air through the plant's roots and the soil-less media. Contaminated air is purified through the roots and then returned completely clean. To accelerate the air circulation, fans are installed inside the system that naturalize clean air 
back into the room. A smart, automated system with sensors helps to analyze the level and need for nutrients, irrigation, or lighting requirements. Users of the NAAVA ILW have the possibility to use an application that tracks how the living wall works, what the system needs, and how successful the living wall is at air purification.

One of the greatest advantages of Naava One is the soil-free growth. It grows plants inorganically, avoiding the growth of mold, smell, and allergens [33]. The flexibility of the system allows the living walls to be placed in any available indoor space or be used as a space divider, improving space efficiency [34]. The Naava One system needs to be constantly plugged in to a source of electricity in order for it to work properly and deliver the necessary amount of nutrients and water to the plants. According to NAAVA, the ILW consumes about $15 \mathrm{kWh}$ per month, which is less than the energy consumption of a microwave [34]. It includes various sensors, a connection to the cloud for identification of indoor environmental changes, real time feedback, air circulation system, and automated irrigation; thus, it does not require much maintenance and irrigation, as the system is fully automated and can be controlled from a phone. The Naava One living wall is the representation of how smart technologies make our lives more efficient and healthier.
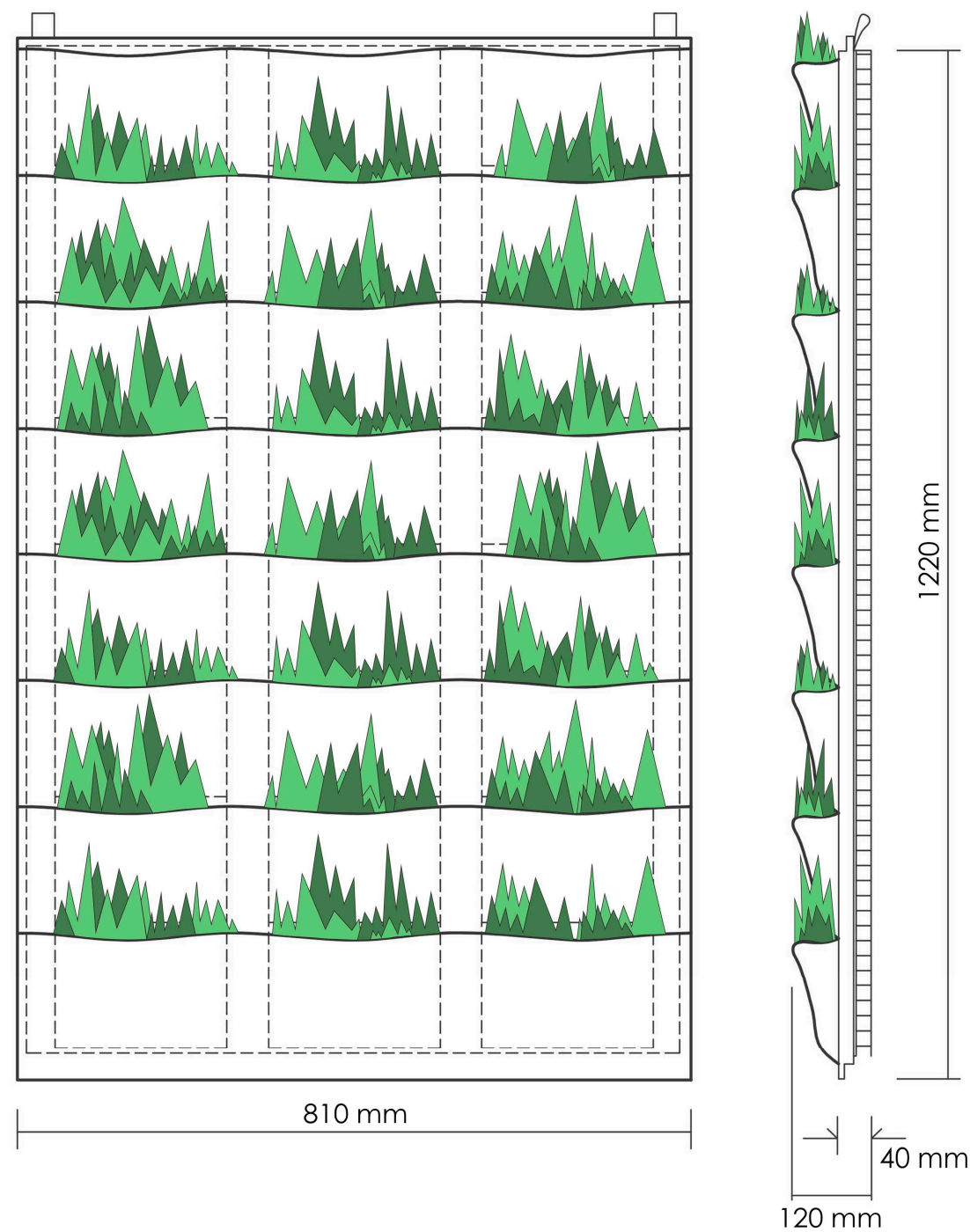

\section{$100 \%$ RECYCLED \\ PLASTIC FELT POCKETS MOUNTED TO RIGID PLASTIC PANELS}

\section{DIMENSIONS}

WIDTH: $310 \mathrm{MM}$

HEIGHT: $1220 \mathrm{MM}$

THINKNESS: $40 \mathrm{MM}$

POCKETS: $120 \mathrm{MM}$

POCKET SIZE

$250 \mathrm{~mm} \times 150 \mathrm{~mm} \times 80 \mathrm{~mm}$

\section{DIMENSIONS}

- LIGHTWEIGHT - 7.5g/sm

- PLANTED WEIGHT: APROX. $2.4 \mathrm{kgs} / \mathrm{sm}$

- MADE FROM INDESTRUCRTBLE, RECYCLED P.E.T. PLASTIC FELT

- EASY-TO-MOUNT WALL

- EASY MODIFICATIONS

- HANING TABS

- ROOT WRAPS INCLUDED

Figure 8. Pocket living wall system based on [32]. 

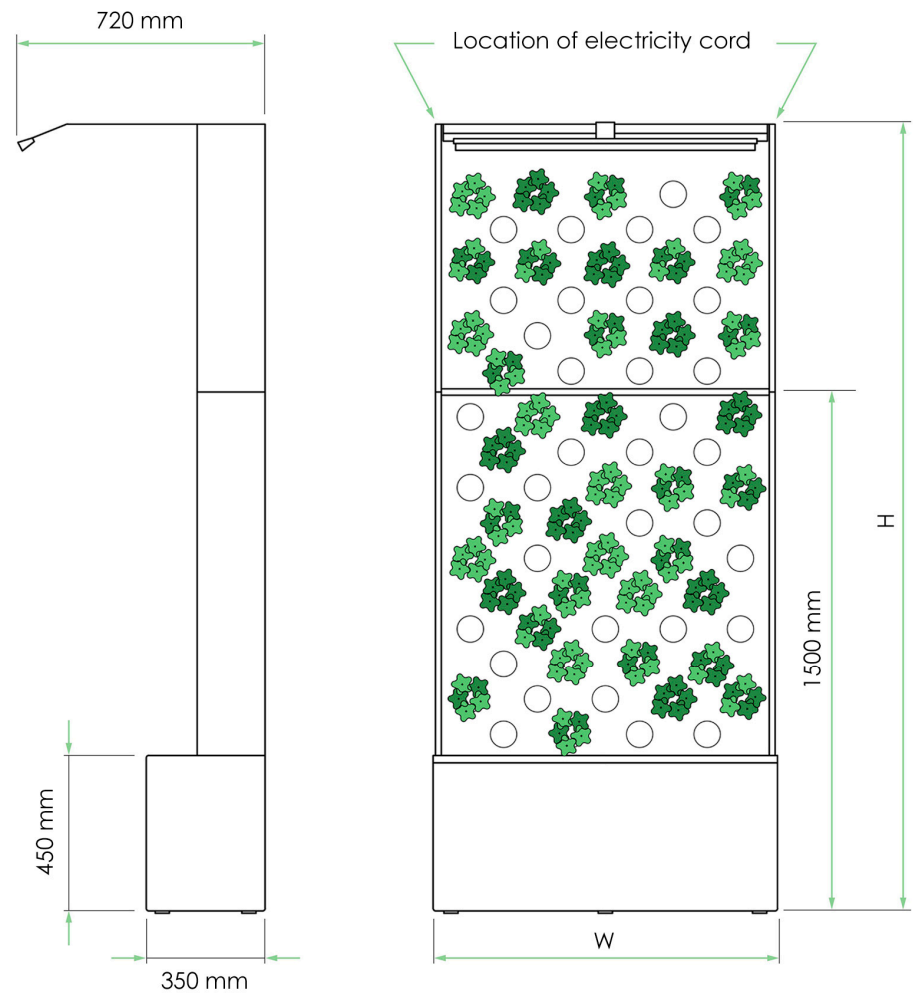

Figure 9. Smart living wall based on [35].

\subsection{Verdanta Flourish Living Wall}

The main component of the Sagegreenlife living wall is the Biotile-a cornerstone organized as a layer of tiles [36] (Figure 10). It is used as a rock fiber and rockwool, which allows an easy and even distribution of water and nutrients to the system [36]. Biotile is a biodegradable material, as it can be recycled and reused later. Its biggest advantage is the stability of the rockwool material, since it does not expand or change in size whether it is in dry or wet, or cold or hot conditions [36].
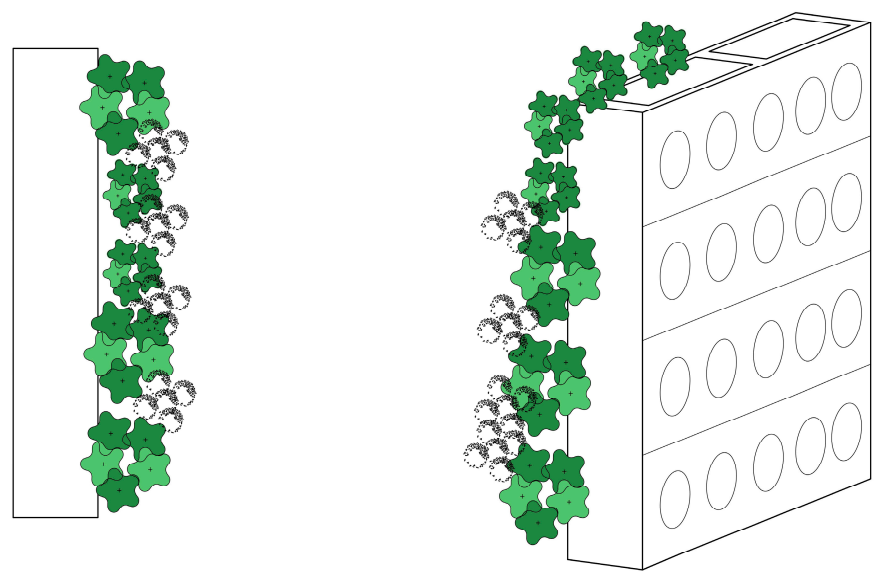

Figure 10. Biotile component overview based on [37].

As shown in Figure 10, Biotile can be used as a modular component to create various interior designs adapted to indoor spatial conditions. An individual tile is composed of twenty compartments in which plants can be inserted. This allows the combination of different plant species and therefore brings more diversity into the design. As can be seen in Figure 11, the irrigation and drainage equipment are located at the bottom of the living 
wall and, therefore, hidden from the eye, allowing a direct interaction with the plants. The system comes with integrated lights mounted on top of the living wall, providing easy installation and maintenance.
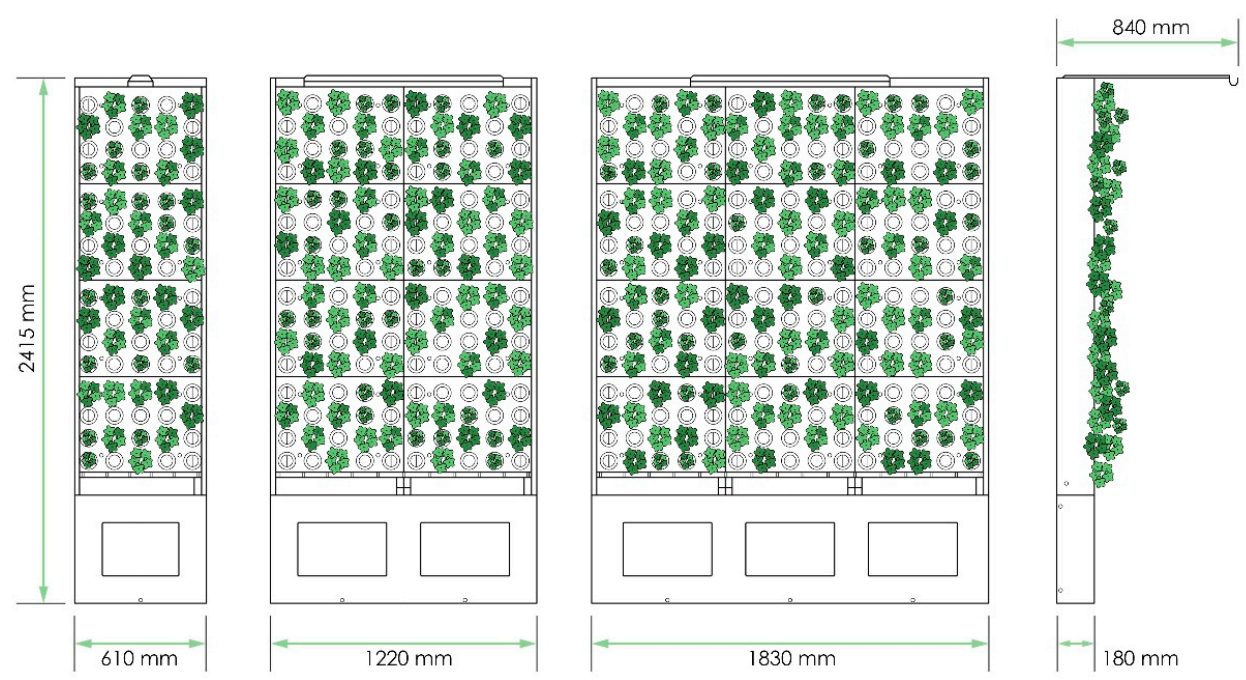

Figure 11. Living wall with Biotile component based on [38].

The irrigation system of Sagegreenlife is fully integrated into the system and concealed inside in order to keep the plant material visible. One of the features of such an irrigation system is the full control of the amount of water, which delivers only the necessary amount that the plants need and avoids any waste. Sagegreenlife living walls (Figure 11) are monitored by the Internet of Things technology, which provides real-time information, alerts, and maintenance requests to protect the plants' health [39]. The system is connected to the living wall over a $4 \mathrm{G}$ cellular data network, including attached sensors and irrigation controllers that ensure the best living wall performance [39].

The presented analysis of current existing living wall systems highlights the diversity of function and broad design solutions that can be utilized in every home. As has been reviewed, the components of the living wall depend on the primary function and the requirements set by the user, such as accessibility, affordability, and labor demand of the system. This authors of this paper believe that ILWs can be designed, transformed and adjusted by the user accordingly, and that they have no limits in expanding their potential. ILWs designed and assembled with essential components can create innovative design solutions of food production, enhancing the value and spatial efficiency of homes.

\section{Discussion}

The decision to implement an ILW should begin with a clear understanding of its purpose and function. The set of living wall components will be determined according to its primary goal. The decision-making process is by far the most important stage, as it determines how the ILW will correspond to the needs of the occupants and what value it will bring to an indoor space and its owner. The analysis has shown that ILWs provide a variety of functions that can benefit the user, however, the primary incentives of one's choice need to be addressed.

\subsection{Affordability}

One of the main challenges of the ILW design is affordability. Nowadays, technological advancements and innovative design approaches strive to find the best solution to meet the target cost. Current design and technologies, with its abundancy of diverse products, provides an opportunity to be affordable, durable, and creative, simultaneously. Recent practices have shown that all of the necessary ILW components can be adapted to meet the user's target cost (Table 1). 
Table 1. Costs related to living wall systems. Note: The choice of components depends on the size and the design of the living wall, where some of them can be optional.

\begin{tabular}{|c|c|c|c|c|}
\hline Components & Type & Category & Time Frame & Cost Range (C\$) \\
\hline $\begin{array}{l}\text { Structural } \\
\text { Support }\end{array}$ & $\begin{array}{l}\text { Plywood Backing } \\
\text { Timber } \\
\text { Galvanized Steel }\end{array}$ & Initial & One Time & $\begin{array}{c}20-30 \mathrm{C} \$ / \mathrm{m}^{2} \\
13-20 \mathrm{C} \$ / 2.5 \mathrm{~m} \\
20-35 \mathrm{C} \$ / \mathrm{m}^{2}\end{array}$ \\
\hline Drainage & $\begin{array}{c}\text { Automated } \\
\text { Felt-Covered Mat } \\
\text { Rear/Bottom Drain }\end{array}$ & Initial & One time & $\begin{array}{c}150-300 \mathrm{C} \$ / \mathrm{Kit} \\
150-200 \mathrm{C} \$ / 1.2 \mathrm{~m} \times 15 \mathrm{~m} \text { roll } \\
80-120 / 1.5 \mathrm{~m} \times 3 \mathrm{~m} \text { system }\end{array}$ \\
\hline Waterproofing & $\begin{array}{l}\text { Waterproof Membrane } \\
\text { Plastic Boards }\end{array}$ & Initial & One time & $\begin{array}{c}50-100 \mathrm{C} \$ / 9 \mathrm{~m} \text { roll } \\
10-20 \mathrm{C} \$ / 0.2 \mathrm{~m} \times 0.3 \mathrm{~m} \text { sheet }\end{array}$ \\
\hline Growth Media & $\begin{array}{c}\text { Pre-Grown } \\
\text { Hydroponic } \\
\text { Pozzolan/Clay Balls } \\
\text { Soil } \\
\text { Fytotextile Fabric }\end{array}$ & Maintenance & Annual & $\begin{array}{c}100-150 \mathrm{C} \$ / 0.1 \mathrm{~m} \text { (100 sheets) } \\
20-25 \mathrm{C} \$ / 100 \text { Sponge Cubes } \\
10-15 \mathrm{C} \$ / 5 \mathrm{~L} \text { bag } \\
20-25 \mathrm{C} \$ / 0.4 \mathrm{~m} \times 0.9 \mathrm{~m} \\
80-100 \mathrm{C} \$ / 0.9 \mathrm{~m} \times 30 \mathrm{~m} \text { sheet }\end{array}$ \\
\hline Vegetation & $\begin{array}{l}\text { Decorative Plants } \\
\text { Edible Plants }\end{array}$ & Maintenance & Annual & $\begin{array}{l}2-20 \mathrm{C} \$ / \text { plant } \\
3-10 \mathrm{C} \$ \text { /plant }\end{array}$ \\
\hline Lighting & $\begin{array}{l}\text { LED } \\
\text { Halogen Bulbs } \\
\text { Fluorescent }\end{array}$ & Maintenance & Every 6 Months & $\begin{array}{c}\text { 4-7 C } \$ / \text { bulb } \\
5-10 \mathrm{C} \$ / \text { bulb } \\
15-50 \mathrm{C} \$ / \text { tube or } \\
6-8 \mathrm{C} \$ / \text { bulb }\end{array}$ \\
\hline Installation & $\begin{array}{c}\text { Self-installation } \\
\text { Installation Assistance }\end{array}$ & Initial & One Time & $100-200 / 0.3 \mathrm{~m} \times 0.3 \mathrm{~m}$ \\
\hline Maintenance & $\begin{array}{l}\text { Structural Maintenance } \\
\text { Vegetation Maintenance }\end{array}$ & Maintenance & $\begin{array}{l}\text { Annual } \\
\text { Regular }\end{array}$ & 300-700 C \$/year \\
\hline
\end{tabular}

Manual irrigation systems, including side feed and tubing systems, are considered the most affordable selection, whereas automated or self-contained recirculation systems tend to be more expensive but efficient in time management, maintenance, and waste generation. Hydroponic growth media can cost more but requires less maintenance expenses in the end, whereas regular soil will cost less initially but will demand more thorough care, which might result in acquiring additional maintenance products. The variety of currently available ILW components will allow one to choose the most affordable design option, which means that a living wall can be installed in small houses as in bigger homes.

\subsection{Maintenance}

Nowadays, technology permits one to save time, money, and to bring more opportunities into a design. A fully automated ILW system minimizes the need for regular inspections and maintenance due to the fact that the system is being checked through a computer, where major changes are made and sent back to the living wall for self-maintenance. This type of living wall is an innovative idea, as it partly replaces the need for manual maintenance. Fully automated ILWs are a good solution for those who do not have time for regular maintenance and for those who do not have basic knowledge about ILW systems and its components. Besides that, an automated system will be advantageous for the elderly population and people with disabilities. Full automation is a big advantage in reducing overuse and the over filling of water and nutrients. The analysis, which is carried out by a computer or sensors, identifies the specific volume of compounds, decreasing expenses of fertilization and water consumption.

\subsection{Air Purification}

Designing an ILW for air purification purposes is a good solution for those who suffer from lung dysfunction, asthmatic disorders, and other breathing problems [40]. In this 
case, the installation of an ILW will help rid the indoor air of contaminants and air borne pollutants such as toluene, ethyl benzene, xylene, and other volatile organic particles [41,42]. Living walls moisturize and oxygenate indoor air by collecting contaminants and dust particles. It is important to take into account the fact that different plant species vary in which specific pollutant they remove. The choice of plants will determine how effectively the living wall will purify indoor air and how it will affect one's health.

\subsection{Food Production and Economic Benefits}

Currently, ILWs are primarily used for air purification and aesthetic purposes, which is caused by the lack of materials examining how edible plants can be integrated into an ILW. Actual environmental challenges result in environmental burdening, an increase of emissions, and resource and waste generation. The variety of suitable edible plants, including vegetables and fruits, can integrate food production into homes following the same ILW system concept. The insertion of edible plants into the indoor environment will not only provide an air purification effect but will also produce fresh vegetables and fruits. The production of edible plants will reduce the need for store bought produce and will create a source of fresh edible plants within the home space. The idea of edible living walls is a good solution for people who are looking for an affordable and accessible source of fresh produce and for those who value naturally grown plants.

\subsection{Aesthetics and Design}

Besides air purification and food production, an ILW can be used as a design tool. The tendency to design indoor spaces with plants is developing rapidly, combining innovative technology and creative design techniques. A space filled with plants positively affects psychological conditions and brings great value to the interior environment.

The abundance of different systems enables the integration of an ILW to any interior setting whilst considering adaptability to existing furniture placement, available area, size, and vertical or horizontal surfaces. The modularity of ILW components allows them to be easily adaptable or to create a variety of patterns onto the walls themselves. The use of a room divider concept or a double-sided mobile living wall will provide an opportunity to divide indoor spaces according to their different functions. This means that big, indoor, ineffective spaces can be divided into rooms or spaces to bring more efficiency and functionality to the existing indoor environment.

\subsection{Well-Being and Stress Reduction}

The psychological benefits of plants have been recognized in a variety of places such as hospitals, schools, and offices. According to Vertical Oxygen, studies show that living walls help increase productivity of college students up to $12 \%$ [43]. The feeling of nature that living walls provide is obtained endlessly without dependence on the season. The installation of a living wall is a good solution for those who experience a psychological imbalance and struggles with feeling overwhelmed, which brings stress and health problems.

\subsection{Accessibility and Climate Independence}

The installation of an ILW is an innovative way to create an accessible, climateindependent source of natural and fresh produce within the home space. Whether an occupant chooses to install an ILW for air purification, design, or food growing purposes, a living wall will be accessible throughout the year. This means that ILWs will have a big impact whether they provide food or purify air, especially in the colder regions of Canada, where the presence of an ILW will create a sense of nature and allow one to grow herbs and vegetables. The implementation of an ILW for food growing is a good solution for those who aim to obtain harvest throughout the year. 


\subsection{Energy Consumption}

During the hot and dry seasons, people struggle with indoor heat, lack of moisture, or over humidification. According to Tirelli, the sunlight absorbed by plants $(50 \%)$ is being reflected in a lower capacity (30\%) [44]. This means that an ILW can be used as a tool to create a cooler and more pleasant indoor environment. As a result, installation of living walls will reduce or fully replace the need for indoor air conditioning and consequently, lower energy consumption and expenses spent to cool indoor spaces.

\subsection{Smart Home Technology}

The rapid development of technology provides more opportunities in designing homes. Nowadays, the abundance of technological products provides opportunities to find the best solution for design, varying from the most affordable to expensive choices. With time, technology became more affordable and can be successfully integrated into interior spaces. Installation of smart ILW systems or a fully automated system, which is wirelessly connected to a phone or computer, allows users to acquire the full potential from a living wall design. Smart living walls are based on computerizing processes such as irrigation, maintenance, lighting, fertilization, and watering. The processes of an ILW can be evaluated through the phone and computer, where a user can monitor the current condition of the living wall. The integration of smart ILWs is the best solution for people who want to be kept updated with technology and lack free time for maintenance such as the elderly or people with disabilities in order to maximize their efficiency.

\section{Conclusions}

The main incentive for ILW development should begin by rethinking the significance of nature connectiveness. With the advent of technology, the integration of green infrastructures into urban fabric became an essential design strategy to preserve the connection between nature and the built environment. Continuous population expansion and city densification have isolated cities from nature and human beings. ILWs can become a part of the home design process, whether it be a house or an apartment. The drive towards the development of edible ILWs derives from social necessity in having a qualified source of fresh produce, its potential user accessibility and affordability, as well as air purification benefits and environmental urban improvement. Current living wall options offer a diverse variety of functions and elements to choose from that can suit all types of preferences. The research has shown that the essential components of a living wall can be obtained and adapted according to the budget, suiting the current indoor context despite its available area and design.

The global pandemic has led to rethinking the importance of indoor spaces and their indoor air quality. Now, with most of the population working remotely, people face an urgent need to improve their state of mental and physical health. The integration of an indoor edible living wall is an opportunity to invest in long-term health improvement. The author believes that indoor living walls provide a gateway to a green and eco-friendly world, which can change the way we think, the way we behave in nature, and change the future that we will live in.

Author Contributions: Conceptualization, D.S.; methodology, D.S. and A.F.; validation, A.F.; formal analysis, D.S. and A.F.; investigation, D.S.; resources, D.S.; data curation D.S. and A.F.; writingoriginal draft preparation, D.S.; writing-review and editing, A.F.; visualization, D.S.; supervision, A.F.; project administration, A.F.; funding acquisition, D.S. and A.F. All authors have read and agreed to the published version of the manuscript.

Funding: This research received no external funding.

Institutional Review Board Statement: Not applicable.

Informed Consent Statement: Not applicable.

Data Availability Statement: Not applicable. 
Conflicts of Interest: The authors declare no conflict of interest.

\section{References}

1. World Health Organization; Hales, S.; Kovats, S.; Lloyd, S.; Campbell-Lendrum, D. Quantitative Risk Assessment of the Effects of Climate Change on Selected Causes of Death, 2030s and 2050s; WHO: Geneva, Switzerland, 2014.

2. Canada, E. Government of Canada. Available online: https://www.canada.ca/en/environment-climate-change/services/ climate-change/ causes.html (accessed on 4 August 2020).

3. Environment and Climate Change Canada. National Inventory Report 1990-2016: Greenhouse Gas Sources and Sinks in Canada; Pollutant Inventories and Reporting Division: Gatineau, QC, Canada, 2018.

4. Kissinger, M. International Trade Related Food Miles-The Case of Canada. Food Policy 2012, 37, 171-178. [CrossRef]

5. Precht, C. We Need Agriculture Back in Our Cities and in Our Minds. Available online: https://www.dezeen.com/2019/03/07 /vertical-farming-agriculture-architecture-cities-chris-precht/ (accessed on 8 March 2019).

6. Roshanafshar, S.; Hawkins, E. Food Insecurity in Canada; Statistics Canada: Ottawa, ON, Canada, 2015.

7. WHO. Monographs on the Evaluation of the Carcinogenic Risks to Human; International Agency for Research on Cancer: Lyon, France, 1999; Volume 71.

8. Gunawardena, K.R.; Steemers, K. Living Wall Influence on Microclimates: An Indoor Case Study. J. Phys. Conf. Ser. 2019, 1343. [CrossRef]

9. Sharp, R.; Sable, J.; Bertram, F.; Mohan, E.; Peck, S. Introduction to Green Walls: Technology, Benefits E Design; Green Roofs for Healthy Cities: Toronto, ON, Canada, 2008; Available online: https://houseaffection.com/introduction-to-green-wallstechnology-benefits-design/ (accessed on 25 April 2021).

10. Manso, M.; Castro-Gomes, J. Green Wall Systems: A Review of their Characteristics. Renew. Sustain. Energy Rev. 2014, $41,863-871$. [CrossRef]

11. Stav, Y. Transfunctional Living Walls-Designing Living Walls for Environmental and Social Benefits. Ph.D. Thesis, Queensland University of Technology, Brisbane City, QLD, Australia, 2016.

12. Riley, B.; de Larrard, F.; Malécot, V.; Dubois-Brugger, I.; Lequay, H.; Lecomte, G. Living Concrete: Democratizing Living Walls. Sci. Total Environ. 2019, 673, 281-295. [CrossRef] [PubMed]

13. LiveWall. How Do I Fertilize my Green Wall? Available online: https://livewall.com/faq-items/how-to-fertilize-a-living-wall/ (accessed on 5 August 2020).

14. Fowdar, H.S.; Hatt, B.E.; Breen, P.; Cook, P.L.; Deletic, A. Designing Living Walls for Greywater Treatment. Water Res. 2017, 110, 218-232. [CrossRef] [PubMed]

15. Maina, G.G.; Brown, J.S.; Gersani, M. Intra-Plant versus Inter-Plant Root Competition in Beans: Avoidance, Resource Matching or Tragedy of the Commons. Plant Ecology 2002, 160, 235-247. [CrossRef]

16. Semchenko, M.; Hutchings, M.J.; John, E.A. Challenging the Tragedy of the Commons in Root Competition: Confounding Effects of Neighbour Presence and Substrate Volume. J. Ecol. 2007, 95, 252-260. [CrossRef]

17. de Kroon, H. How Do Roots Interact? Science 2017, 318, 1562. [CrossRef] [PubMed]

18. Carpenter, S. Growing Green Guide: A Guide to Green Roofs, Walls \& Facades in Melbourne and Victoria, Australia. Aust. State Vict. 2014, 142.

19. Sharma, P.; Vertical Gardens. An Innovative Element of Green Building Technology. In Proceedings of the Internal Conference (GYANODAY 2015), Greater Nodia, India; 2015; p. 42. Available online: https://www.semanticscholar.org/paper/VerticalGardens-\%E2\%80\%93-An-Innovative-Element-of-Green-Sharma/ee068d428e93f40459c9512eeadae8341ee52246 (accessed on 25 April 2021).

20. Dunnett, N.; Kingsbury, N. Planting Green Roofs and Living Walls; Timber Press: Portland, OR, USA, 2008.

21. Giordano, R.; Montacchini, E.; Tedesco, S.; Perone, A. Living Wall Systems: A Technical Standard Proposal. Energy Procedia 2017, 111, 298-307. [CrossRef]

22. ANS Living Wall Guide. Available online: https://www.ansgroupglobal.com/sites/default/files/fields/downloads/files/ANS_ Living_Wall_Product_Guide\%202019.pdf (accessed on 9 August 2020).

23. Yildirim, N.N. The Effects of Living Walls on Users at the Commercial Interiors. J. Strategic Int. Stud. $2018,13,95$.

24. EPA. An Introduction to Indoor Air Quality (IAQ). In Washington: US Environmental Protection; EPA: Washington, DC, USA, 2009.

25. Fell, D. Vertical Gardening: Grow Up, Not Out, for More Vegetables and Flowers in Much Less Space; Rodale: New York, NY, USA, 2011.

26. Susorova, I. Green Facades and Living Walls: Vertical Vegetation as a Construction Material to Reduce Building Cooling Loads. In Eco-Efficient Materials for Mitigating Building Cooling Needs; Woodhead Publishing: Cambridge, UK, 2015; pp. 127-153.

27. GSky. Home. Available online: https://gsky.com/ (accessed on 2 March 2020).

28. Versa Wall CAD \& Specs. Available online: https://gsky.com/versa/cad-specs/ (accessed on 2 March 2020).

29. ANS Global. ANS Living Wall CAD DWG Files. How Does a Living Wall Work? Available online: https://www.ansgroupglobal. com/living-wall/technical (accessed on 25 May 2020).

30. Florafelt Living Wall Guide. Available online: https:/ / florafelt.squarespace.com/florafelt-living-wall-guide (accessed on 25 May 2020).

31. Florafelt. Florafelt Living Wall Systems. Available online: https:// florafelt.com/ (accessed on 9 August 2020).

32. Florafelt Pocket Panels Spec Sheets. Available online: https:// florafelt.com/florafelt-pocket-panels-spec-sheets (accessed on 25 May 2020). 
33. NAAVA. NAAVA Product Brochure. Available online: https:/ / www.naava.io/en/download-materials (accessed on 25 May 2020).

34. NAAVA. Not a Normal Green Wall. Available online: https://www.naava.io/en/ (accessed on 9 August 2020).

35. NAAVA. NAAVA Design Guide. Available online: https:/ / www.naava.io/en/download-materials (accessed on 25 May 2020).

36. Sagegreenlife. Living Plant Wall Systems. Available online: https://www.sagegreenlife.com/ (accessed on 9 August 2020).

37. Sagegreenlife. Verdanta Flourish Product Sheet. Available online: https://www.sagegreenlife.com/product/flourish/ (accessed on 9 August 2020).

38. Vertical Garden Watering System \& Technology. Available online: https://www.sagegreenlife.com/process/technology/ (accessed on 20 June 2020).

39. Sagegreenlife. Comparative Analysis. Available online: https://www.sagegreenlife.com/process/technology/ (accessed on 20 June 2020).

40. Ottelé, M.; Perini, K.; Fraaij, A.L.A.; Haas, E.M.; Raiteri, R. Comparative Life Cycle Analysis for Green Façades and Living Wall Systems. Energy Build. 2011, 43, 3419-3429. [CrossRef]

41. Wolverton, B.C.; Eco Friendly Houseplants, Weidenfeld and Nicolson, London. Released in US as How to Grow Fresh Air. Phoenix Illustrated. 1996. Available online: http:/ / www.wolvertonenvironmental.com/freshair.html (accessed on 25 April 2021).

42. Wolverton, B.C. How to Grow Fresh Air; Penguin Books: New York, NY, USA, 1996.

43. Vertical Oxygen. Health Benefits of a Living Wall. Available online: https://verticaloxygen.com/living-walls/benefits/ (accessed on 7 August 2020).

44. Tirelli, G. Top 10 Benefits of Living Green Walls. Available online: https://ecobnb.com/blog/2019/04/living-green-wallsbenefits / (accessed on 7 August 2020). 